\title{
Odporność korozyjna wybranych powłok nakładanych metodą tamponową
}

\author{
Corrosion resistance of selected coatings \\ deposited by the brush plating method
}

\section{Streszczenie}

W artykule przedstawiono wyniki badań korozyjnych wybranych powłok nakładanych metodą tamponową. Przedmiotem badań były powłoki metalowe $(\mathrm{Ni}, \mathrm{Cu}+\mathrm{Ni})$ i powłoki kompozytowe metalowo-ceramiczne $\left(\mathrm{Cu}+\mathrm{Si}_{3} \mathrm{~N}_{4}\right.$, $\mathrm{NiW}+\mathrm{Si}_{3} \mathrm{~N}_{4}$ ). Badania odporności na korozję wykonano metodą potencjodynamiczną w $0,5 \mathrm{M} \mathrm{NaCl}$. Przedstawiono również wyniki badań metalograficznych i pomiarów mikrotwardości.

Słowa kluczowe: metoda tamponowa, powłoki, korozja
Abstract

The paper presents the results of the corrosion resistance investigation of selected coatings deposited by the brush plating method. The metal $(\mathrm{Ni}, \mathrm{Cu}+\mathrm{Ni})$ and composite metal-ceramic composite $\left(\mathrm{Cu}+\mathrm{Si}_{3} \mathrm{~N}_{4}, \mathrm{NiW}+\mathrm{Si}_{3} \mathrm{~N}_{4}\right)$ coatings have been produced in the frame of conducted research. The investigation of corrosion resistance has been performed using the potentiodynamic method in the $0.5 \mathrm{M}$ solution of $\mathrm{NaCl}$. The results of microhardness measurements and microscopic investigation of the surface and cross-section of the coating have been also included.

Keywords: brush plating, coatings, corrosion

\section{Wstęp}

Zagadnienia związane z modyfikacja właściwości powierzchni elementów maszyn i urządzeń stanowią obecnie istotny kierunek prowadzonych prac badawczych. Powierzchnia elementu w czasie eksploatacji jest narażona na równoczesne oddziaływanie czynników mechanicznych i korozyjnych. Istotne jest zatem uzyskanie jednocześnie jej odpowiedniej odporności na zużycie mechaniczne i oddziaływanie czynnika korozyjnego. Jedną z metod umożliwiających realizację tego zadania jest metoda tamponowa (ang. brush plating, selective plating, spot plating, swab plating).

Metoda ta stanowi odmianę metody galwanicznej nakładania powłok. W porównaniu z nią ma wiele zalet, takich jak: krótszy czas nakładania powłoki, niższy koszt procesu, łatwość obsługi stosowanych urządzeń. W metodzie tamponowej elektrolit jest przenoszony na powierzchnię elementu pokrywanego za pomocą tamponu nasuniętego na elektrodę połączoną z dodatnim biegunem źródła prądu, natomiast element pokrywany połączony jest $z$ biegunem ujemnym. Znaczna liczba dostępnych w metodzie elektrolitów umożliwia otrzymywanie powłok jedno- i wielowarstwowych, które w zależności od ich budowy i rodzaju mogą cechować się określonymi właściwościami, takimi jak odporność na zużycie, odporność na działanie czynników korozyjnych, wysoka twardość czy odpowiednia zwilżalność powierzchni. Ze względu na dużą mobilność urządzeń stosowanych w metodzie tamponowej i charakter procesu możliwe jest nakładanie powłok na powierzchnie elementów maszyn w miejscu ich pracy, niejednokrotnie bez konieczności ich demontażu. Na rysunku 1 pokazano przykłady powłok nałożonych metodą tamponową.

W tablicy I zestawiono wybrane elektrolity produkcji chińskiej, cechujące się wg producenta m.in. odpornością na korozję i/lub na zużycie.

\section{Dr inż. Jarosław Grześ - Politechnika Warszawska, Instytut Technik Wytwarzania.}



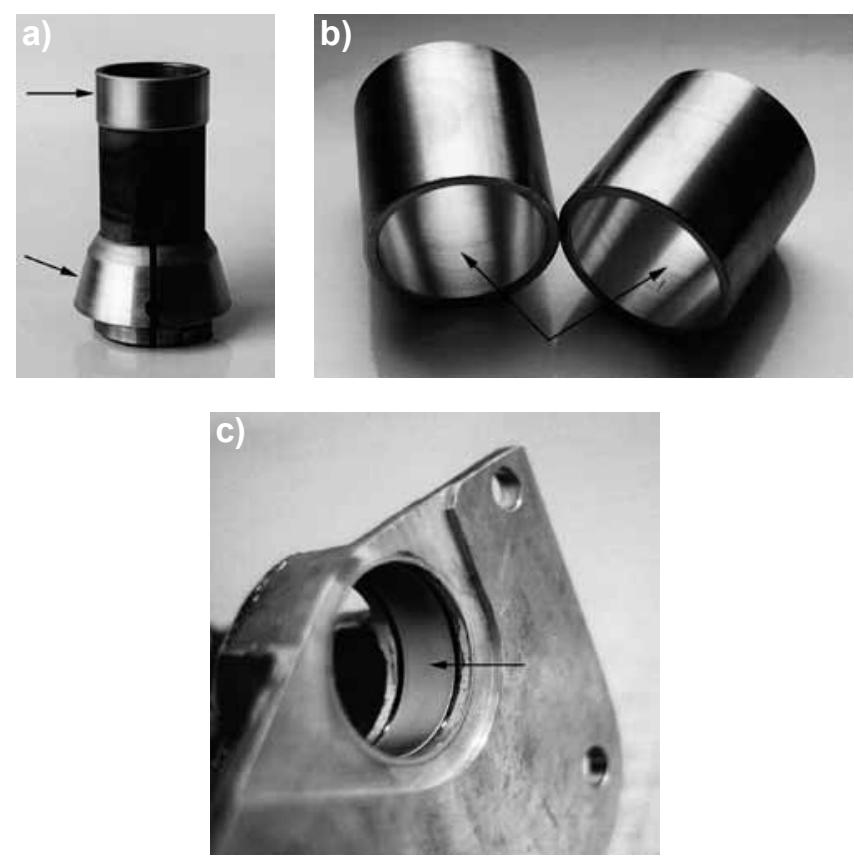

Rys. 1. Powłoki nałożone metodą tamponową: a) NiW, b) $\mathrm{Cu}, \mathrm{c}) \mathrm{Ni}$ Fig. 1. Coatings deposited by the brush planting method a) NiW, b) $\mathrm{Cu}, \mathrm{c}) \mathrm{Ni}$

Tablica I. Wybrane elektrolity i ich właściwości [1] Table I. Plating solutions and their properties [1]

\begin{tabular}{|c|c|c|c|c|c|}
\hline $\begin{array}{c}\text { Nazwa } \\
\text { elektrolitu }\end{array}$ & $\mathrm{K}_{\mathrm{j}}$ & $\mathrm{P}$ & $\mathrm{S}_{\mathrm{o}}$ & $Q_{E}$ & Uwagi \\
\hline $\begin{array}{l}\text { Copper } \\
\text { Alkaline - } 1\end{array}$ & 60 & 0,079 & 9,8 & 710 & \multirow{2}{*}{$\begin{array}{c}\text { Warstwy } \\
\text { podkładowe } \\
\text { niskie } \\
\text { naprężenia } \\
\text { pozostające }\end{array}$} \\
\hline $\begin{array}{l}\text { Copper High } \\
\text { Build Alkaline }\end{array}$ & 80 & 0,079 & 9,8 & 953,6 & \\
\hline $\begin{array}{l}\text { Nickel } \\
\text { High Speed }\end{array}$ & 50 & 0,104 & 12,7 & 562,9 & \multirow{4}{*}{$\begin{array}{l}\text { Powłoki } \\
\text { odporne } \\
\text { na zużycie }\end{array}$} \\
\hline $\begin{array}{l}\text { Nickel } \\
\text { Compact } \\
\text { High Speed }\end{array}$ & 50 & 0,113 & 12,7 & 562,9 & \\
\hline Indium & 65 & 0,04 & $5 \div 12,7$ & 952,6 & \\
\hline \begin{tabular}{|l|} 
Nickel \\
Tungsten Alloy
\end{tabular} & 85 & 0,214 & 1,2 & 844,4 & \\
\hline $\begin{array}{l}\text { Copper } \\
\text { Semi-Bright }\end{array}$ & 64 & 0,152 & $7,6 \div 12,7$ & 710 & \multirow{2}{*}{$\begin{array}{c}\text { Powłoki } \\
\text { ochronne } \\
\text { i dekoracyjne } \\
\text { odporność } \\
\text { na korozję }\end{array}$} \\
\hline Cobalt & 38 & 0,037 & 3,8 & 514 & \\
\hline Cadium Acidic & 152 & 0,121 & 3,5 & 1583 & \multirow{3}{*}{$\begin{array}{l}\text { Odporność } \\
\text { na korozję }\end{array}$} \\
\hline \begin{tabular}{l|} 
Cadmium \\
Low Hydrogen \\
Non-Embritling \\
\end{tabular} & 100 & 0,02 & 30 & 1212 & \\
\hline Zinc Alkaline & 65,4 & 0,02 & 12,7 & 1403 & \\
\hline $\begin{array}{l}\text { Chromium } \\
\text { Acidic }\end{array}$ & 44 & 0,545 & 0,625 & 736,1 & $\begin{array}{l}\text { Odporność } \\
\text { na zużycie } \\
\text { i korozję }\end{array}$ \\
\hline \multicolumn{6}{|c|}{$\begin{array}{l}\mathrm{K}_{\mathrm{j}} \text { - koncentracja jonów metalu w elektrolicie, g/l } \\
\mathrm{P} \text { - współczynnik zużycia mocy, } \mathrm{Ah} / \mathrm{dm}^{2} \star \mu \mathrm{m} \\
\mathrm{S}_{\mathrm{o}} \text { - szybkość nakładania, } \mu \mathrm{m} / \mathrm{min} \\
Q_{E} \text { - wydajność elektrolitu, } \mathrm{dm}^{2} / / * \mu \mathrm{m}\end{array}$} \\
\hline
\end{tabular}

Przedstawione wyniki badań wybranych powłok metalowych i kompozytowych uzyskano w cyklu prac prowadzonych w Zakładzie Inżynierii Spajania Politechniki Warszawskiej związanych z badaniem powłok nakładanych metodą tamponową. Badane powłoki nakładano urządzeniem produkcji chińskiej DSQ-15, stosując uchwyty elektrodowe ZDB-1(II) i elektrody grafitowe SM 1. Pomiary mikrotwardości wykonano metodą Vickersa, wykorzystując twardościomierz MPT-3 oraz mikroskop świetlny Neophot 21 wyposażony w przystawkę do pomiarów mikrotwardości. Obserwacje mikroskopowe prowadzono na mikroskopie Olympus przy powiększeniach 200 i 1000 razy. W celu określenia odporności powłok na korozję wykorzystano metodę potencjodynamiczną i środowisko $0,5 \mathrm{M} \mathrm{NaCl}$.

\section{Powłoki metalowe}

Przedmiotem badań były powłoki metalowe niklowe $(\mathrm{Ni})$ i miedziano-niklowe ( $\mathrm{Cu}+\mathrm{Ni})$. Powłoki zastały nałożone na powierzchnię stali 45 . W ramach wstępnego przygotowania powierzchnie poddano szlifowaniu w celu uzyskania odpowiedniej ich chropowatości. Proces nakładania obejmował następujące etapy:

- odtłuszczanie elektrolityczne,

- aktywację powierzchni,

- nakładanie podkładowej warstwy niklowej polepszającej przyczepność właściwej warstwy do podłoża,

- nakładanie warstw $\mathrm{Ni}$ i Cu.

Zastosowane elektrolity i parametry nakładania powłok $\mathrm{Ni}$ i $\mathrm{Cu}+\mathrm{Ni}$ zestawiono w tablicy II.

Tablica II. Parametry nakładania powłok $\mathrm{Ni}$ i $\mathrm{Cu}+\mathrm{Ni}$

Table II. The deposition parameters of $\mathrm{Ni}$ and $\mathrm{Cu}+\mathrm{Ni}$ coatings

\begin{tabular}{|c|c|c|c|c|}
\hline Elektrolit & $\begin{array}{c}\text { Napięcie } \\
\text { nakł. } \\
\text { V }\end{array}$ & $\begin{array}{c}\text { Czas } \\
\text { nakł. } \\
\mathrm{s}\end{array}$ & \begin{tabular}{|c|} 
Prędkość \\
przesuwu \\
elektrody \\
$\mathrm{m} / \mathrm{min}$
\end{tabular} & Uwagi \\
\hline Elektroclean\#1 & 12 & 30 & $\sim 6$ & $\begin{array}{l}\text { Czyszczenie } \\
\text { elektrolityczne }\end{array}$ \\
\hline Activator\#2 & 8 & 15 & \multirow{2}{*}{$\sim 4$} & \multirow{2}{*}{$\begin{array}{l}\text { Aktywacja } \\
\text { powierzchni }\end{array}$} \\
\hline Activator\#3 & 20 & 30 & & \\
\hline \multirow{2}{*}{ Nickel Special } & 18 & $3 \div 5$ & \multirow{2}{*}{$\sim 6$} & \multirow{2}{*}{$\begin{array}{c}\text { Warstwa } \\
\text { podkładowa } \\
(\mathrm{g} \approx 1 \div 3 \mu \mathrm{m})\end{array}$} \\
\hline & 12 & $3 \div 5$ & & \\
\hline $\begin{array}{l}\text { Copper } \\
\text { Semi-Bright }\end{array}$ & 6 & 240 & $\sim 10$ & $\begin{array}{l}\text { Warstwa Cu } \\
(\mathrm{g} \approx 20 \mu \mathrm{m})\end{array}$ \\
\hline \multirow{3}{*}{$\begin{array}{l}\text { Nickel } \\
\text { Semi-Bright }\end{array}$} & \multirow{3}{*}{8} & 100 & \multirow{3}{*}{$\sim 10$} & $\begin{array}{l}\text { Warstwa Ni } \\
(g \approx 5 \mu \mathrm{m})\end{array}$ \\
\hline & & 200 & & $\begin{array}{l}\text { Warstwa Ni } \\
(\mathrm{g} \approx 10 \mu \mathrm{m})\end{array}$ \\
\hline & & 300 & & $\begin{array}{l}\text { Warstwa Ni } \\
(\mathrm{g} \approx 15 \mu \mathrm{m})\end{array}$ \\
\hline
\end{tabular}


Pomiędzy poszczególnymi operacjami nakładania próbki płukano w wodzie. Po zakończeniu etapu nakładania płukano je w alkoholu etylowym i suszono w strumieniu ciepłego powietrza. Przygotowano następujące zestawy próbek:

- zestaw I: powłoka Ni o grubości $5 \mu \mathrm{m}$,

- zestaw II: powłoka Ni o grubości $10 \mu \mathrm{m}$,

- zestaw III: powłoka Ni o grubości $15 \mu \mathrm{m}$,

- zestaw IV: powłoka Cu+Ni - o grubościach odpowiednio $20 \mu \mathrm{m}$ i $5 \mu \mathrm{m}$,

- zestaw V: powłoka $\mathrm{Cu}+\mathrm{Ni}$ - o grubościach odpowiednio $20 \mu \mathrm{m}$ i $10 \mu \mathrm{m}$.

Pomiary mikrotwardości wykazały, że twardość uzyskanych powłok (mierzona na przekroju poprzecznym powłoki) wynosi średnio 430 HV0,04 dla warstw Ni oraz 221 HV0,04 dla warstw $\mathrm{Cu}$. Obserwacje mikroskopowe wykazały pęknięcia na powierzchni i przekroju poprzecznym powłok niklowych, spowodowane naprężeniami wewnętrznymi w powłokach. Typowy obraz pęknięć w powłokach niklowych, nakładanych metodą tamponową, pokazano na rysunku 2. Wyniki badań odporności korozyjnej przedstawiono na rysunku 3 w postaci krzywych polaryzacji anodowej. Na rysunku 4 porównano krzywe polaryzacji anodowej otrzymane dla powłoki niklowej o grubości $5 \mu \mathrm{m}$ i powłok niklowych poddanych procesowi borowania w temperaturze $650^{\circ} \mathrm{C}$ i $850^{\circ} \mathrm{C}$, nakładanych metodą tamponową, oraz powłoki niklowej naniesionej chemicznie [2].

a)

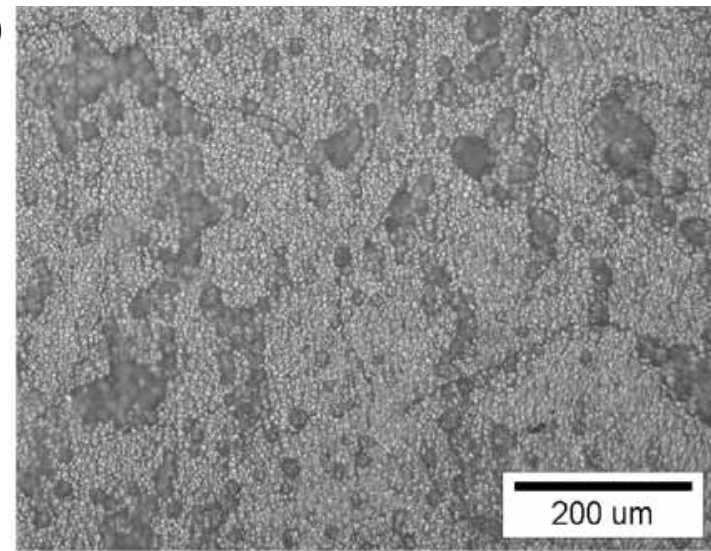

b)

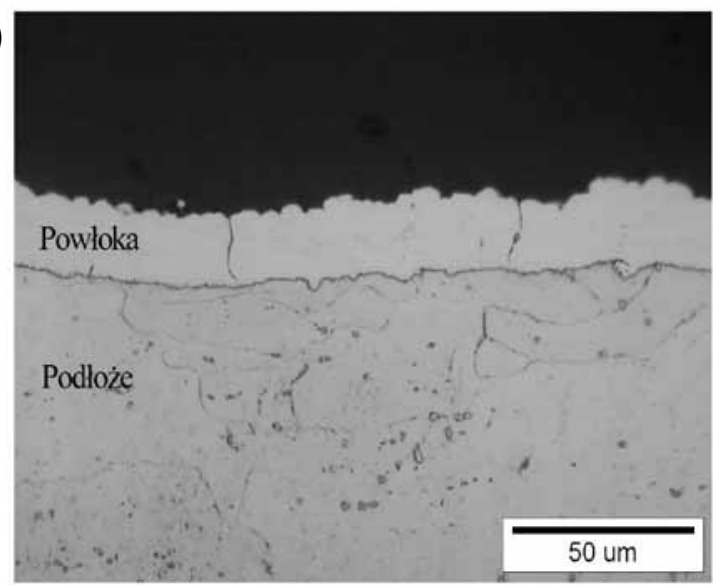

Rys. 2. Pęknięcia w powłoce Ni: a) powierzchnia powłoki, b) przekrój poprzeczny

Fig. 2. Cracks observed in $\mathrm{Ni}$ coating: a) the coating surface, b) the coating cross-section

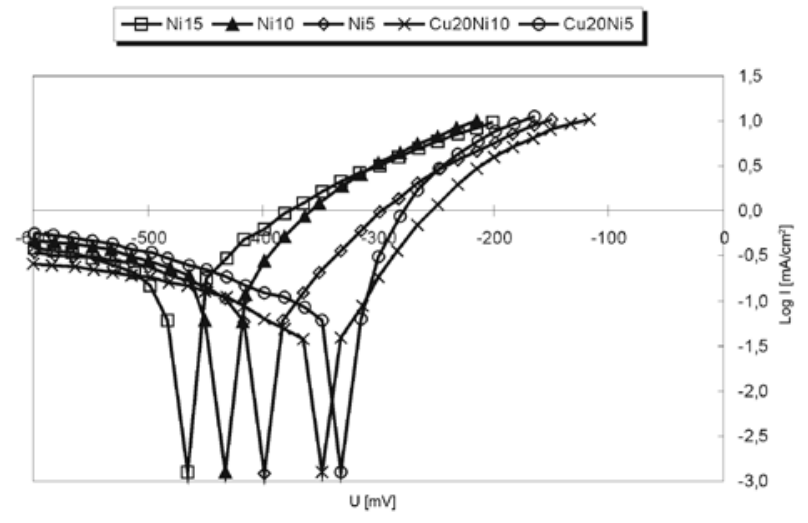

Rys. 3. Krzywe polaryzacji anodowej powłok Ni i Cu+Ni nakładanych metodą tamponową, I - gęstość prądu korozji, U - potencjał

Fig. 3. The anodic polarization curves for $\mathrm{Ni}$ and $\mathrm{Cu}+\mathrm{Ni}$ coatings deposited by the brush plating method, I - current dencity, $\mathrm{U}$ - potential

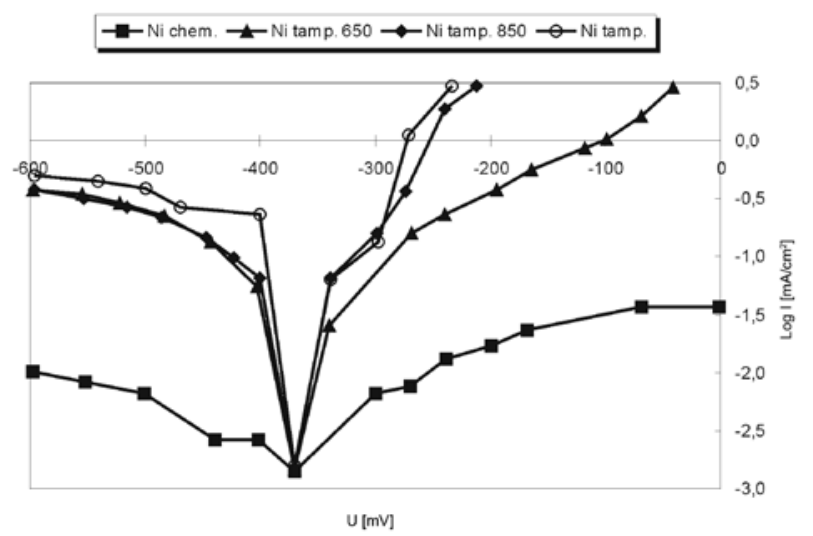

Rys. 4. Krzywe polaryzacji anodowej powłok Ni o grubości $5 \mu \mathrm{m}$, nakładanych metodą tamponową i chemicznie, I - gęstość prądu korozji, U - potencjał

Fig. 4. The anodic polarization curves for $5 \mu \mathrm{m}$ Ni coatings deposited by both brush plating and chemical methods, I - current dencity, $\mathrm{U}$ - potential

\section{Powłoki kompozytowe}

Jednym z zastosowań metody tamponowej jest możliwość nakładania powłok kompozytowych metalowo-ceramicznych [3, 4], co dodatkowo podnosi jej użyteczność. Badania korozyjne przeprowadzono dla powłok kompozytowych $\mathrm{Cu}+\mathrm{Si}_{3} \mathrm{~N}_{4}$ i $\mathrm{NiW}+\mathrm{Si}_{3} \mathrm{~N}_{4}$. Powłoki nakładano na powierzchnię stali 18G2A z elektrolitów Copper Alkaline\#1 i Nickel Tungsten Alloy. Jako fazę niemetaliczną zastosowano proszek $\mathrm{Si}_{3} \mathrm{~N}_{4}$ o wielkości ziarna $0,5 \mu \mathrm{m}$. Elektrolit podczas nakładania mieszano w celu utrzymania zawiesiny proszku w elektrolicie. Proces nakładania obejmował te same etapy jak w przypadku powłok metalowych. Parametry nakładania powłok $\mathrm{Cu}+\mathrm{Si}_{3} \mathrm{~N}_{4}$ i NiW+Si${ }_{3} \mathrm{~N}_{4}$ zestawiono w tablicy III. W celach porównawczych nałożono powłoki $\mathrm{Cu}$ i NiW z elektrolitów niezawierających proszku $\mathrm{Si}_{3} \mathrm{~N}_{4}$, przy napięciu nakładania odpowiednio $11 \mathrm{~V}$ i $12 \mathrm{~V}$. 
Tablica III. Parametry nakładania powłok $\mathrm{Cu}+\mathrm{Si}_{3} \mathrm{~N}_{4}$ i NiW $+\mathrm{Si}_{3} \mathrm{~N}_{4}$

Table III. The deposition parameters of $\mathrm{Cu}+\mathrm{Si}_{3} \mathrm{~N}_{4}$ and $\mathrm{NiW}+\mathrm{Si}_{3} \mathrm{~N}_{4}$ coatings

\begin{tabular}{|c|c|c|c|c|}
\hline Elektrolit & $\begin{array}{c}\text { Napięcie } \\
\text { nakładania, } V\end{array}$ & $\begin{array}{c}\text { Czas } \\
\text { nakładania, s }\end{array}$ & $\begin{array}{l}\text { Prędkość przesuwu } \\
\text { elektrody, } \mathrm{m} / \mathrm{min}\end{array}$ & Uwagi \\
\hline Elektroclean\#1 & 12 & 30 & $\sim 6$ & Czyszczenie elektrolityczne \\
\hline Activator\#1 & 12 & 45 & $\sim 4$ & Aktywacja powierzchni \\
\hline \multirow{2}{*}{ Nickel Special } & 18 & $3 \div 5$ & \multirow{2}{*}{$\sim 6$} & \multirow{2}{*}{ Warstwa podkładowa $(g \approx 1 \div 3 \mu \mathrm{m})$} \\
\hline & 12 & $3 \div 5$ & & \\
\hline Copper Alkaline\#1 & $8 / 11 / 14$ & 900 & $\sim 6$ & $\begin{array}{c}\text { Warstwa } \mathrm{Cu}+\mathrm{Si}_{3} \mathrm{~N}_{4} \text {, zawartość proszku } \\
\text { w elektrolicie: } 10,30,50 \mathrm{~g} / \mathrm{l}\end{array}$ \\
\hline $\begin{array}{l}\text { Nickel Tungsten } \\
\text { Alloy }\end{array}$ & $9 / 12 / 15$ & 900 & $\sim 6$ & $\begin{array}{c}\text { Warstwa NiW+Si } \mathrm{N}_{4} \text {, zawartość proszku } \\
\text { w elektrolicie: } 10,30,50 \mathrm{~g} / \mathrm{l}\end{array}$ \\
\hline
\end{tabular}

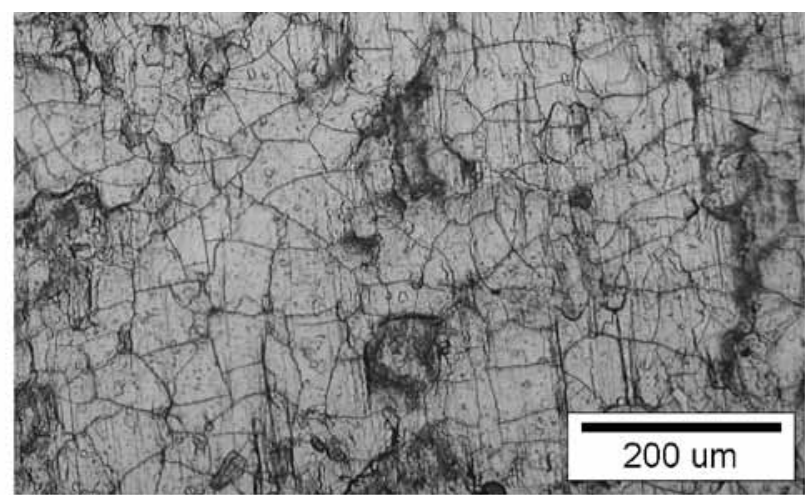

Rys. 5. Pęknięcia w powłoce NiW

Fig. 5. Cracks in NiW coating

a)

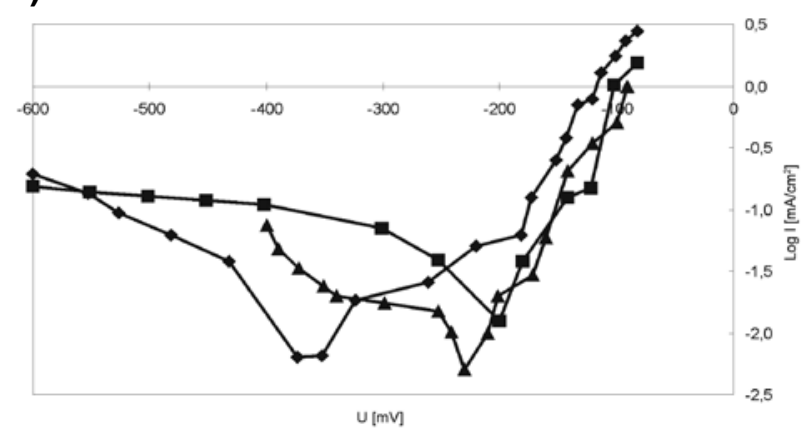

b)

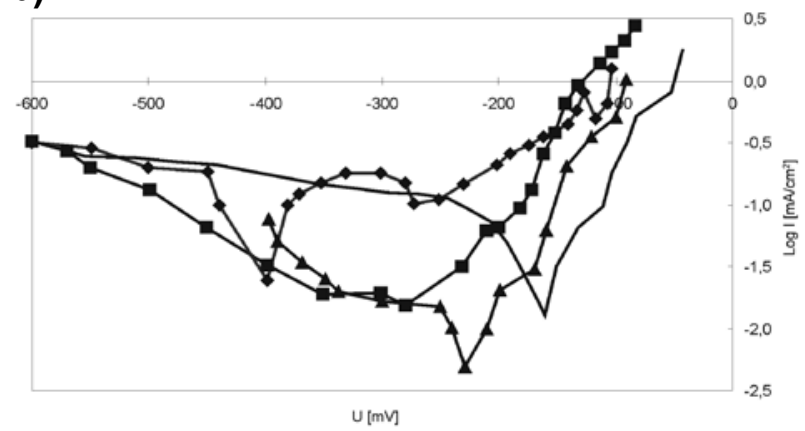

Rys. 6. Krzywe polaryzacji anodowej powłok $\mathrm{Cu}+\mathrm{Si}_{3} \mathrm{~N}_{4}$ nakładanych metodą tamponową: a) dla zawartości proszku $\mathrm{Si}_{3} \mathrm{~N}_{4}$ w elektrolicie $30 \mathrm{~g} / \mathrm{l}$ i różnego napięcia nakładania, b) dla napięcia nakładania $11 \mathrm{~V}$ i różnej zawartości proszku $\mathrm{Si}_{3} \mathrm{~N}_{4}$ w elektrolicie, I - gęstość prądu korozji, U - potencjał

Fig. 6. The anodic polarization curves for $\mathrm{Cu}+\mathrm{Si}_{3} \mathrm{~N}_{4}$ coatings: a) for $30 \mathrm{~g} / \mathrm{l}$ content of $\mathrm{Si}_{3} \mathrm{~N}_{4}$ powder and several deposition voltages, b) for the deposition voltage of $11 \mathrm{~V}$ and several contents of $\mathrm{Si}_{3} \mathrm{~N}_{4}$ powder in the electrolyte, I - current dencity, U - potential
W wyniku pomiarów mikrotwardości stwierdzono, że twardość powłok w zależności od napięcia nakładania i zawartości $\mathrm{Si}_{3} \mathrm{~N}_{4}$ w elektrolicie zawierała się w granicach $120 \div 230 \mathrm{HVO}, 02$ (powłoki $\mathrm{Cu}+\mathrm{Si}_{3} \mathrm{~N}_{4}$ ) i $500 \div 1000 \mathrm{HV} 0,02$ (powłoki $\mathrm{NiW}+\mathrm{Si}_{3} \mathrm{~N}_{4}$ ) i była wyższa od twardości powłok $\mathrm{Cu}$ i Ni nakładanych bez dodatku $\mathrm{Si}_{3} \mathrm{~N}_{4}$. Podobnie jak w przypadku powłok niklowych, również w powłokach NiW stwierdzono występowanie pęknięć (rys. 5). Wyniki badań odporności korozyjnej w postaci krzywych polaryzacji anodowej przedstawiono na rysunkach 6 i 7.
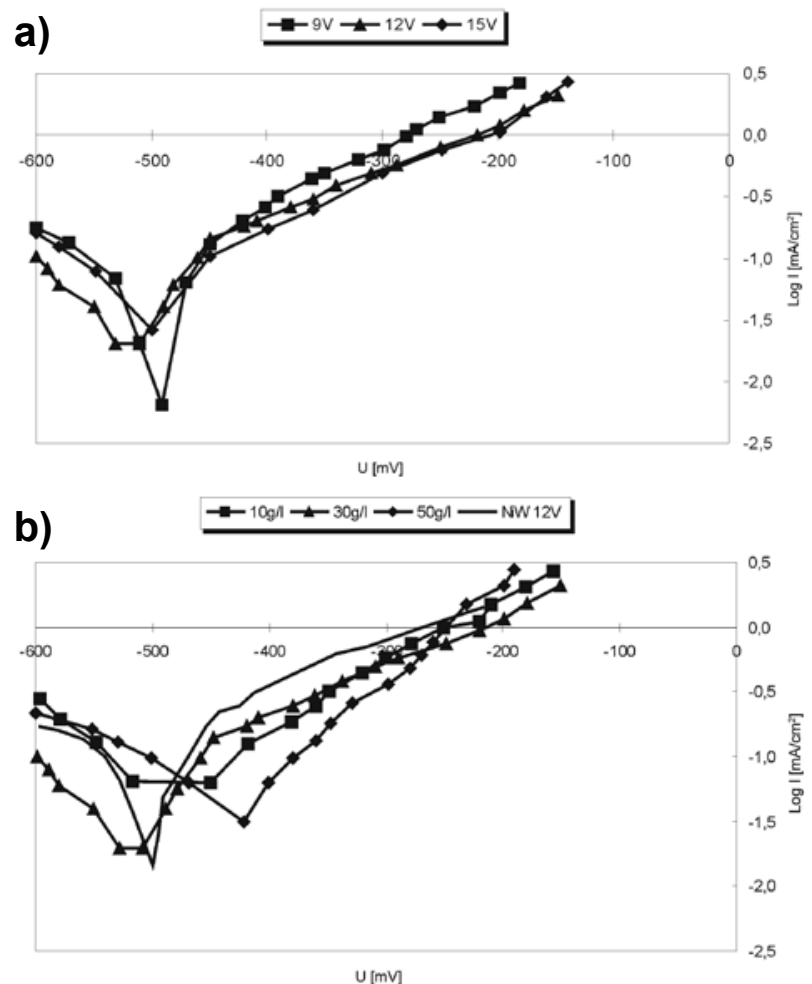

Rys. 7. Krzywe polaryzacji anodowej powłok $\mathrm{NiW}+\mathrm{Si}_{3} \mathrm{~N}_{4}$ nakładanych metodą tamponową: a) dla zawartości proszku $\mathrm{Si}_{3} \mathrm{~N}_{4}$ w elektrolicie $30 \mathrm{~g} / \mathrm{l}$ i różnego napięcia nakładania, b) dla napięcia nakładania $12 \mathrm{~V}$ i różnej zawartości proszku $\mathrm{Si}_{3} \mathrm{~N}_{4}$ w elektrolicie, I - gęstość prądu korozji, U - potencjał

Fig. 7. The anodic polarization curves for $\mathrm{NiW}+\mathrm{Si}_{3} \mathrm{~N}_{4}$ coatings: a) for $30 \mathrm{~g} / \mathrm{l}$ content of $\mathrm{Si}_{3} \mathrm{~N}_{4}$ powder and several deposition voltages, b) for the deposition voltage of $12 \mathrm{~V}$ and several contents of $\mathrm{Si}_{3} \mathrm{~N}_{4}$ powder in the electrolyte, I - current dencity, $U$ - potential 


\section{Wnioski}

Obserwacje mikroskopowe wykazały dobre przyleganie badanych powłok do materiału podłoża. Dla powłok $\mathrm{Ni}$ i NiW zaobserwowano występowanie siatki pęknięć, charakterystycznej dla tego rodzaju powłok. Wyraźnie większą skłonność do pęknięć zaobserwowano w powłoce NiW. Badane powłoki kompozytowe metalowo-ceramiczne charakteryzują się wyższą twardością w porównaniu z powłokami uzyskanymi z elektrolitów niezawierających proszku $\mathrm{Si}_{3} \mathrm{~N}_{4}$.

Analizując krzywe polaryzacji anodowej stwierdzono, że powłoki metalowe Ni cechuje mniejsza odporność na korozję w porównaniu z powłokami $\mathrm{Cu}+\mathrm{Ni}$ (rys. 3). Niższa odporność korozyjna powłok metalowych $\mathrm{Ni}$ jest spowodowana obecnością pęknięć w powłoce, które sprzyjają zwiększeniu szybkości korozji. Zastosowanie w celu uszczelnienia powłoki warstwy Cu podniosło jej odporność korozyjną. Zaobserwowano spadek odporności korozyjnej ze wzrostem grubości powłoki Ni. W odniesieniu do powłok Ni nakładanych chemicznie powłoki Ni nakłada- ne metodą tamponową cechują się obniżoną odpornością korozyjną. Zastosowanie procesu borowania spowodowało stosunkowo niewielki wzrost odporności korozyjnej powłok Ni nakładanych tamponowo. W przypadku powłok kompozytowych $\mathrm{Cu}+\mathrm{Si}_{3} \mathrm{~N}_{4}$ w porównaniu z powłoką $\mathrm{Cu}$ zaobserwowano niższą odporność korozyjną. Powłoki NiW+ $\mathrm{Si}_{3} \mathrm{~N}_{4}$ charakteryzowały się porównywalną lub lepszą odpornością korozyjną w porównaniu z powłoką NiW. Porównując oba rodzaje powłok kompozytowych, wyższą odporność na korozję stwierdzono dla powłok $\mathrm{Cu}+\mathrm{Si}_{3} \mathrm{~N}_{4}$, natomiast odporność korozyjna powłok $\mathrm{NiW}+\mathrm{Si}_{3} \mathrm{~N}_{4}$ jest mniej zależna od zawartości proszku $\mathrm{Si}_{3} \mathrm{~N}_{4}$ w elektrolicie i napięcia nakładania. Na podstawie wyników badań powłok metalowych $\mathrm{Cu}-\mathrm{Ni}$ należy przypuszczać, iż zastosowanie warstwy podkładowej Cu podwyższyłoby odporność korozyjną powłok $\mathrm{NiW}+\mathrm{Si}_{3} \mathrm{~N}_{4}$.

Prezentowane wyniki badań zostały uzyskane w ramach prac badawczych $[2,5,6]$ oraz prac własnych autora.

\section{Literatura}

[1] Brush plating solutions instruction manual, China National Machinery Import \& Export Corporation, Beijing Branch.

[2] Opracowanie metod wytwarzania oraz badania struktury i właściwości nowych warstw wieloskładnikowych i kompozytowych. Grant KBN nr 3 P407 05804.

[3] Grześ J.: Wytwarzanie metodą tamponową metalowych i metalowo-ceramicznych powłok kompozytowych. Kompozyty nr 5/2002, Wydawnictwo Politechniki Częstochowskiej, s. $359 \div 363$.
[4] Grześ J.: Powłoki kompozytowe $\mathrm{Cu}+\mathrm{Si}_{3} \mathrm{~N}_{4}$ i Ni+Si $\mathrm{N}_{4}$ nakładane metodą tamponową, Kompozyty nr 6/2003 (3(2003)6), Wydawnictwo Politechniki Częstochowskiej.

[5] Warstwy kompozytowe otrzymywane w procesie nakładania tamponowego. Program badawczy „Nowe Materiały”, Politechnika Warszawska.

[6] Nanokompozyty ceramiczno-metalowe $z$ gradientem właściwości. Grant KBN nr PZB-KBN-013/T08/15.

\section{Odczyty techniczne}

\section{Organizowane przez Sekcję Spawalniczą OW SIMP, dostępne dla członków SIMP, NOT oraz wszystkich sympatyków spawalnictwa.}

\begin{tabular}{|c|c|}
\hline \multicolumn{2}{|c|}{$\begin{array}{c}\text { Wydział Inżynierii Produkcji Politechniki Warszawskiej } \\
\text { Gmach Nowy Technologiczny } \\
\text { Warszawa, ul. Narbutta 85, sala NT 129 } \\
\text { Dojazd tramwajami: 17 i 33 }\end{array}$} \\
\hline $\begin{array}{c}\text { Data } \\
\text { i godzina }\end{array}$ & \multicolumn{1}{c|}{ Prelegent, temat odczytu } \\
\hline $\begin{array}{c}\text { 27-03-2014 } \\
\text { godz. 1700 }\end{array}$ & $\begin{array}{c}\text { Dr inż. Michał tagosz, Zakład Inżynierii Spajania PW } \\
\text { Wymiarowanie konstrukcji spawanych z wykorzystaniem nowoczesnych narzędzi modelowania } \\
\text { trójwymiarowego. Prezentacja projektowania oraz przykładów zrealizowanych konstrukcji. }\end{array}$ \\
\hline
\end{tabular}

